\title{
From Santa Claus to serious business: Where should FOCAC go next?
}

\author{
By lan Taylor \\ St. Andrews University, Scotland
}

The Forum on China-Africa Cooperation (FOCAC) is a platform established by the People's Republic of China (PRC) in collaboration with African countries for collective consultation and dialogue. Established in 2000, FOCAC ministerial summits take place every three years, alternatively in China and then Africa. The existence of FOCAC might be best seen as the institutionalization of Sino-African relations at a time of intensified interactions and following a period of exponential growth in such linkages. It is also then formalization of relationships which have been long in existence and which can trace their direct origins back over 50 years.

The first Forum met in October 2000 in Beijing and was attended by nearly 80 ministers from 44 African countries. The second ministerial conference was held in Addis Ababa, Ethiopia, in December 2003 and passed the Addis Ababa Action Plan (2004-2006). The FOCAC Summit and the third ministerial conference were held in Beijing from November 2006, while FOCAC IV met in Sharm el-Sheikh, Egypt, in November 2009. FOCAC V meets in Beijing in the last quarter of 2012 and it is in this context that this work seeks to critically evaluate the FOCAC.

17 a general problem with FOCAC is the fact that China is very much in control of the whole process and it is Beijing that sets the agenda and the declarations and outcomes.

The initial meeting essentially had three main objectives. First, the Forum was part of Beijing's overall strategy in its foreign policy to at least rhetorically declare its aim of overhauling the global order and advance a traditional hostility to "hegemony." This domination, dressed up as "globalization" (qianqiuhua), is at times seen as detrimental to the autonomy and sovereignty of China and needs careful management. By extension, this applies to the developing world. As the then Chinese Premier, Zhu Rongji said at the 2000 Forum, Sino-African ties help "build up our capacity against possible risks, which will put us in a better position to participate in economic globalization and safeguard our economic interests and economic security." They also "improve the standing of the developing countries in North-South dialogue so as to facilitate the establishment of a fair and rational new international political and economic order". Such principles are sound and make perfect sense for African countries struggling with underdevelopment and a broadly hostile international economic environment. Yet the question I wish to explore is whether or not FOCAC is the most suitable vehicle to advance such an agenda.

\section{Who Sets the Agenda?}

A general problem with FOCAC is the fact that China is very much in control of the whole process and it is Beijing that sets the agenda and the declarations and outcomes. Africa plays a bit-part at best. A key issue facing Africa's engagement with FOCAC is that the continent lacks a consistent and unified collective policy to connect with Beijing. That "China has an Africa policy. Africa doesn't have a China policy" (The Nation, (Nairobi), June 12, 2006) is a common enough charge, but it has real consequences. At FOCAC III for instance, Africa was unsuccessful in developing a combined negotiating approach that might have shaped the debate and been advantageous to the Continent. 'Whereas the FOCAC declaration present[ed] a 
genuine platform for pragmatic co-operation, to Africa's advantage, Africa's failure to form a unified voice could seriously hamper its ability to determine the terms and general direction of the interaction [because] rather than work as a bloc, Africa continues to negotiate with China on a country-by-country basis' (Business in Africa (London), December 20, 2006). As a result, Africa was left largely on the side-lines at what turned out to be a Chinese extravaganza of largesse and ostensible generosity. Though the meeting was supposedly about Sino-African cooperation and mutual exchange, the reality was very different. Africa was in fact the spectator. As one African commentary put it after FOCAC III:

African leaders flocked to this event as if they had wanted to swear an oath of allegiance to the African continent's new tutor. Standing on a red carpet in the Great Hall of the People, President Hu Jintao could not hide his joy when, hand stretched out, he welcomed African heads of state one after another. Under the cameras of Chinese TV, attentive onlookers could discern the message that the Chinese President was aiming to send. Shortly after what recalled a traditional feature of China's relations with its neighbours in the past, the 'kow-towing' ceremony, Hu Jintao's announcement of a flurry of measures to help Africa showed that, behind the discourse of equality and the carnival atmosphere of the Summit, the Sino-African relationship is characterized by an undeniable asymmetry (Gaye, 2007: 136).

1 Whilst FOCAC commits itself to engagement with Africa's various regional bodies and to the African Union in particular, there is no official AU view on Sino-African ties.

Whilst FOCAC commits itself to engagement with Africa's various regional bodies and to the African Union in particular, there is (somewhat incredibly) no official AU view on Sino-African ties, whether these be seen as positive with regard to their benefits or negative with respect to any downsides. Interviewing AU staff in Addis, it is clear to me at least that most $\mathrm{AU}$ bureaucrats have not the faintest idea when evaluating Sino-African ties, though they are appreciative of the new Chinese-built AU headquarters and the various fully-funded trips to China (with the attendant per diems) that they can accumulate. But such lack of reflexivity means that at the continental level there is an almost total lack of any coherent African voice to shape the relationships that FOCAC is supposed to engender. In these circumstances, even if China's policymakers wanted to make FOCAC more "Africa-centric" (whatever that might mean), it would be difficult for Beijing policymakers to engage with any unified voice.

\section{Africans in Charge?}

Of course, the above milieu is by no means unique to China-Africa ties and it might be averred that there is no unified African voice on anything and so it is perhaps understandable that FOCAC has played out as it has. As The Economist noted, 'Africa's leaders could also play their hands rather better. They should talk to each other as well as their hosts in Beijing. If they negotiated as a block, they could drive a harder bargain. Just as China insists that foreigners enter into joint ventures with its companies, so Africans should make sure they get China's know-how, not just its money' (The Economist (London), October 26, 2006). This in fact has become a problem for Beijing: 
Some Chinese officials....worry that the forum needs to broaden out from its

focus on economic issues and provide a wider platform for engagement in spheres such as culture, technology and politics. The fear is that by focussing on economic engagements, especially on those carrying the self-imposed requirement of being "win-win", china is putting itself under excessive pressure and as African partners do gradually become more engaged, is risking raising expectations to a point where it can no longer realistically expect to satisfy its partners (Raine, 2009: 81).

This indeed is a serious problem and will be returned to below. Suffice to say that Africa's leadership has, in general, promoted and fostered dependent relationships with the Western capitalist powers that have their origins in the colonial period and there is a danger that FOCAC may simply reproduce this dependency. Given the historic failure of most African leaders to critically do anything about Africa's place in the global political economy, this is a distinct possibility. As any historian of Africa knows, external actors have consumed the continent's resources and have added little to African self-development. In these circumstances, African elites attending forums such as FOCAC can, from a particular perspective, be seen as characters reduced to beggars angling for some Chinese largesse, rather than development-conscious participants and certainly not "partners". Is this too harsh? I don't believe so. The behaviour of Africa's elites in the past does not give great grounds for optimism and there is a real concern that they will not use FOCAC for the promotion of development, but rather squander the diverse opportunities thrown up by renewed and accelerated Chinese engagement. This is where China needs to carefully manage (and direct) the future of FOCAC.

1 Such charges of African responsibility become ever more urgent when one considers the nature of contemporary China's political economy.

Whilst of course recognising the structural constraint that African elites operate within (albeit many of them do their best to reproduce this), engagement with China is ultimately up to African actors. It is the host that establishes the rules on foreign investment and it is the host country's responsibility to take advantage of China's increased interest in Africa. Only Africans can develop their continent and its natural resources, not China or any other state.

\section{Will the Real China Please Stand Up?}

Such charges of African responsibility become ever more urgent when one considers the nature of contemporary China's political economy. FOCAC's promises and pledges are made in the assumption that what Beijing says, Beijing gets, and that Chinese companies and corporations mesh together as part of China's "grand strategy". Thus when FOCAC promises that it will promote Chinese trade with Africa, it will and FOCAC will be the decisive factor in any resultant growth. Nothing could be further from the truth. Whilst Beijing's policymakers may earnestly seek to regulate Chinese business practices in Africa and encourage trade, their ability to do so is extremely limited. Indeed, the more China liberalizes, the less easy it is to control private businesses domestically, let alone in far-off Africa. This is a major conundrum for the Chinese government and undermines the effectiveness of FOCAC as a body that makes decisive issuing of orders. 
In fact, FOCAC may actually undermine Chinese policy in Africa in the sense that it reifies the popular perception common in Africa and elsewhere that China is and remains a centrally controlled, monolithic actor. As one commentary put it,

The Chinese state is often viewed as a machine whose parts all mesh smoothly. In fact, the system of central control and coordination is largely a sham. Closer to the mark is Kenneth Lieberthal's use of the term "fragmented authoritarianism" to characterize the regime. The problems of fraud and workplace fatalities - which persist despite what must in all fairness be acknowledged as serious central-government campaigns against them-expose ... the Chinese state's inability [not only] to regulate society but also ... to get its own agents to do their jobs. Some officials are simply corrupt and wink at dishonest or dangerous enterprises in return for bribes. Other officials, particularly at the local level, see millions of people looking for work and want to help generate jobs even if it means tolerating unsafe or unsavoury businesses. Besides, cash-strapped local governments rely on such activities for tax income, while central decrees often appear as nothing but unfunded mandates. (Wang Shaoguang, 2003: 39).

1 Just as Beijing has long had difficulty controlling what companies, domestic or foreign, do in China, its own call to "go global" (zouchuqu) has undermined its formerly strong control over Chinese companies acting overseas.

This problem is only growing as China reengages with the global economy under the conditions of de facto liberal capitalism and domestic trends spread overseas, even whilst FOCAC contends that the summits have decisive influence on Sino-African matters. Why this may undermine Chinese policy aims is simple. When Shell engages in unsavoury activities in Nigeria's Delta region, no one blames the British Prime Minister and no one makes a direct link between Shell and 10 Downing Street. Yet if a Chinese corporation acts in an unscrupulous fashion in Africa, "the Chinese" are instantly castigated, and Hu Jintao is almost personally implicated. FOCAC in this sense compounds the problem as, particularly when the summit is held in China, African leaders are certainly given the impression that China's Africa policies are under the firm control of Beijing. Yet when one examines even state-owned companies, actual state control is often nominal and even the largest Chinese companies, which remain under direct government control, are motivated by competition and the profit margin and behave autonomously. None of this is acknowledged by the sort of rhetoric that emanates from FOCAC meetings.

In fact, just as Beijing has long had difficulty controlling what companies, domestic or foreign, do in China, its own call to "go global" (zouchuqu) has undermined its formerly strong control over Chinese companies acting overseas. Control over external investment has already been relaxed, and on-going reforms progressively make it easier for companies to act alone. Although Beijing has made both concerted efforts to educate Chinese traders operating in Africa about local labour laws and safety standards and patriotic appeals to protect the image of China abroad, there is the distinct possibility it has failed on both counts. In these circumstances, 'The conception of a rich and powerful China that can ... have a significant impact on policymakers across the world sits rather uneasily with analyses of serious domestic 
problems' (Breslin, 2007: 27). This is problematic for Beijing policymakers if and when Chinese companies do not deliver or misbehave, as FOCAC has been carefully crafted to give the impression that the central state is indeed in charge of operations. Yet developments associated with marketization, combined with deepening corruption at many levels of the Chinese polity, compound any coherent attempts at control from

Beijing and undermine FOCAC. In short, the more Beijing loosens its grip, the harder it will be to restore it, a fact that impacts all levels of society as well as actors overseas.

\section{Reining in Expectations}

The disjuncture between the "real" political economy of China and the myth of a monolithic unitary state becomes particularly acute when it comes to Beijing managing African expectations regarding what FOCAC can (and should) deliver. In fact, since FOCAC III in 2006 there has been a certain retreat from an arguably overgenerous position held by China. FOCAC III itself was the biggest ever high-level conference on African affairs outside of the continent. It was also the largest and highest-level gathering of Chinese and African leaders in Sino-African history. Twenty-four African leaders attended, with government ministers and representatives from China and 48 African countries taking part in the summit. The size of the conference could be gauged by the fact that 1,700 delegates attended, with representatives from more than 20 organizations of the United Nations and African regional organizations attending and more than 1,000 reporters, including about 300 from Africa, covering events.

\section{II has been a consensus that both China and Africa are trying to establish a new type of China-Africa Strategic Partnership, the core feature being win-win cooperation.

At the summit, President Hu Jintao revealed an eight-point plan to be the framework for Chinese efforts post-FOCAC III. These eight points were, namely:

1. Double China's 2006 assistance to Africa by 2009;

2. Provide $\$ 3$ billion of preferential loans and $\$ 2$ billion of preferential buyer's credits to Africa in the next three years;

3. Set up a China-Africa development fund which will reach $\$ 5$ billion to encourage Chinese companies to invest in Africa and provide support to them;

4. Build a conference centre for the African Union to support African countries in their efforts to strengthen themselves through unity and support the process of African integration;

5. Cancel debt in the form of all the interest-free government loans that matured at the end of 2005 owed by the heavily indebted poor countries and the least developed countries in Africa that have diplomatic relations with China;

6. Further open up China's market to Africa by increasing from 190 to over 440 the number of export items to China receiving zero-tariff treatment from the least developed countries in Africa having diplomatic ties with China;

7. Establish three to five trade and economic cooperation zones in Africa in the next three years; and

8. Over the next three years, train 15,000 African professionals; send 100 senior agricultural experts to Africa; set up 10 special agricultural technology demonstration 
malaria] and building 30 malaria prevention and treatment centres to fight malaria in Africa; dispatch 300 youth volunteers to Africa; build 100 rural schools in Africa; and increase the number of Chinese government scholarships to African students from the current 2,000 per year to 4,000 per year by 2009 .

As a Ugandan newspaper framed it: "Training professionals, building hospitals, sending youth volunteers, providing grants to help in the fight against malaria, among so many other initiatives, China will be all over Africa like skin on body [sic]" (New Vision (Kampala), November 4, 2006). The debt cancelation was similarly well received, being cast by one Liberian analysis as "relie[ving] the Liberian nation from matured debts . . . the PRC has indeed invigorated the spirit of planners and financial executives in charting courses that will once more see the Nation as being creditworthy and an adherent to instruments legally-binding" (The Analyst (Monrovia), November 3, 2006.) To give tangible expression to this eight-point plan, during FOCAC III, China offered a package of measures in support of African development, namely to set a target of $\$ 100$ billion in Sino-Africa trade by 2010 (this target was actually reached in 2008). Such munificence is unlikely to be repeated-and nor should it.

\section{It has been a consensus that both China and Africa are trying to establish a new type of China-Africa Strategic Partnership, the core feature being win-win cooperation.}

Though FOCAC IV was, like all previous FOCACs, a bonanza of developmental assistance projects and loans, what was interesting was that compared to the proposals that emanated from FOCAC III, cooperation in international relations moved higher up the priority list, replacing economic cooperation (i.e. hand-outs) and directly next to political cooperation. It was likely that in the context of the on-going financial crisis, which had hit both China and Africa to differing degrees, cooperation at the international level was deemed crucial. Thus mention of the G-20 as a vehicle to stabilize and manage the global political economy was made. The assertions regarding reforms of the United Nations and financial institutions to reflect increased African involvement were routine nods in that direction but also did reflect the feeling within Beijing that the developing world was and is bound to play a more and more important role in international affairs.

Equally, Beijing needs African support on various international issues. According to one Chinese commentator, Liu Haifang of the Institute of West Asian and African Studies in Beijing, "the most dramatic change in the new Sharm el-Sheikh Action Plan from the previous Beijing Action Plan [was] the absence in the new plan of any equivalent to the eye-catching pledge in the 2006 document to double China's aid assistance to African countries" (quoted in Business Day (Johannesburg), November 9 , 2006). Instead, the $\$ 10$ billion in preferential loans was inserted and devoted specifically for infrastructure, highlighted as a key priority for Sino-African cooperation. Whilst the constraints of the financial crisis no doubt helped explain aspects of this development (the non-appearance of such eye-catching statements as witnessed at FOCAC III), Liu notes that the reason for this also sprang from domestic Chinese processes:

After the 2006 Summit, a common theme in the extensive literature on China's aid assistance to Africa, was criticism of what was seen as inadequate transparency in the application of funds, and questioning of the apparent ambiguity between seeking 
economic profit and providing development assistance and aid. This may well have led to reflection and readjustment of the definition of China's official development assistance. It seems likely that a deliberate decision has been taken to avoid conspicuous words such as 'double aid' that were used in the previous plan and which stimulated too much close attention (ibid.).

A further commentator in fact noted the importance of:

Clarify[ing] the nature of Chinese aid to Africa and to specify its amounts. Indeed, the announcement of a doubling (in flow) of the aid between 2006 and 2009 [did] not refer to any baseline. The lack of clarity surrounding this announcement [was] a double-edged sword for the Chinese: on one hand it [made] it impossible to critically monitor how well commitments are being met, but it also create[d] expectations from recipient African nations. While each country knows what it receives and might expect the doubling of aid on a bilateral basis, the promise of Forum on China-Africa doubling has been made at the continent scale. The issue of aid allocation per country has never been settled and Chinese arbitrations start to make some African countries unhappy (Asia Times, November 17, 2006).

However, even with such an evident scaling-back, a question that FOCAC IV raised and which has become ever-more apparent as the summits have progressed, is the issue of sustainability and also the unrealistic expectations of African governments in relation to China in Africa and the purpose of FOCAC. Indeed, it has become clear that some elements of African opinion have entered into a dependency mind-set with regard to China's rise in Africa. For instance, in the aftermath of FOCAC IV it emerged that Gaggawala Wambuzi, the minister of state for trade for Uganda had appealed "to the Chinese people and government that we would like to occupy the correct position" in world trade. That is hardly up to China!

\section{Noticeably, during his 2009 tour to Africa, Hu Jintao had sought to reassure the continent about Beijing's determination to fulfil its FOCAC III commitments.

Noticeably, during his 2009 tour to Africa, Hu Jintao had sought to reassure the continent about Beijing's determination to fulfil its FOCAC III commitments while Wen Jiabao played the role of seeking to fend off the ever-increasing expectations of new aid pledges. The burden of these extremely high expectations, where China is presumed-uncritically - to be the new messiah in Africa is a very heavy load for Beijing to shoulder. Indeed, African governments need to reign in their wild expectations. FOCAC's de facto status as an early Christmas present for African states has become less and less sustainable. Aligning Chinese engagement with the African continent's priorities, rather than willy-nilly accepting (and expecting) gifts from China clearly became apparent by the time of FOCAC IV.

\section{Conclusion}

Ultimately, neither Beijing, nor Africa's leaders are "in charge" of FOCAC's concrete results. Africa has no credible China policy and China's African policy is compromised by the nature of the Chinese state and economy in the way it can-or cannot directthe multitude of Chinese actors engaging with the continent. In this sense, whilst FOCAC does have achievements and is a marker of Chinese interest in Africa, we should not exaggerate its effectiveness or detect too much in the way of it as a defining triennial event in Sino-African ties. In fact, China's relations with the continent 
are ever more "normal" and the value-added nature of FOCAC beyond the symbolism (however important) is questionable. For African recipients of course, they are enthusiastic about such summits as they invariably come away with new aid commitments that help solidify their positions of authority back home and possibly with new resources to lubricate their patronage machines. But from the Chinese perspective, where China's trade with Africa is on an ever-upward trajectory, the need for FOCAC is less and less clear.

In other words, if FOCAC were to disappear overnight, would Chinese relations with Africa-both economically and politically-suffer? The answer to this is of course open, but one cannot help feel that the way Sino-African relations are constructed at present, business would pretty much take care of itself in exactly the same way that Africa continues to engage with and trade with other parts of the world. This would of course be without the fanfare and razzmatazz that we observe every three years when FOCAC comes to town, but would also free Beijing from the increasingly wild expectations that some African quarters have with regard what will emanate from the next summit and help free China's leadership of the perception that they are fully in charge-and thus to blame if and when things go wrong. Yet with the leadership's hold on power predicated on this very imagery of centralised control, one doubts if the Chinese leadership would be prepared to take such a bold and pragmatic step. Symbolism and spin then may be said to be at the root of the whole FOCAC enterprise and works at various levels and is directed both towards Africa, towards the world and towards the Chinese population.

\section{Bibliography}

Breslin, S. (2007) China and the Global Political Economy Basingstoke: Palgrave.

Gaye, A. (2007) "China in Africa: After the Gun and the Bible . . . a West African

Perspective" in Chris Alden, Ricardo Soares de Oliveira, and Dan Large (eds.) China Returns to Africa: A Rising Power and a Continent Embrace Cambridge: Cambridge University Press.

Raine, S. (2009) China's African Challenges London: Routledge.

Wang Shaoguang (2003) "The Problem of State Weakness," Journal of Democracy 14, no. 1.

Dr. Ian Taylor is a Professor in International Relations and African Politics in the School of International Relations, University of St. Andrews. He also Chair Professor in the School of International Studies, Renmin University of China (the highest rank a non-Chinese academic can hold at a Chinese university), Professor Extraordinary in Political Science at Stellenbosch University, South Africa and an Honorary Professor in the Institute of African Studies, Zhejiang Normal University, China. 歷期 